\title{
PREDIKSI KONDISI KEUANGAN PADA PERUSAHAAN SEKTOR PERTAMBANGAN DI BURSA EFEK INDONESIA
}

\author{
Ni Kadek Tina Rasminiati ${ }^{1}$ \\ Luh Gede Sri Artini \\ ${ }^{1,2}$ Fakultas Ekonomi dan Bisnis Universitas Udayana, Bali, Indonesia \\ e-mail: Tinarasminiati07@gmail.com
}

\begin{abstract}
ABSTRAK
Kondisi keuangan merupakan suatu keadaan yang menunjukkan tingkat kesehatan perusahaan yang sesungguhnya. Tujuan penelitian adalah mengetahui pengaruh current asset turnover, total asset turnover, days sales in receivables, cash flow to total debt, dan debt to asset terhadap financial distress. Sampel penelitian yaitu 24 perusahaan sektor pertambangan di BEI periode 2012-2016. Metode pengumpulan data menggunakan observasi nonparatisipan dan regresi logistik sebagai teknik analisis data. Hasil penelitian ini menemukan bahwa: current asset turnover memiliki pengaruh negatif tidak signifikan terhadap financial distress, total asset turnover berpengaruh negatif signifikan terhadap financial distress, days sales in receivables memiliki pengaruh positif tidak signifikan terhadap financial distress, cash flow to total debt memiliki pengaruh negatif tidak signifikan terhadap financial distress, dan debt to asset berpengaruh berpengaruh positif signifikan terhadap financial distress.
\end{abstract}

Kata kunci : kondisi keuangan, financial distress, dan regresi logistik.

\section{ABSTRACT}

Financial condition is a condition that shows the level of company health. The purpose of this study is to determine the effect of current asset turnover, total asset turnover, days sales in receivables, cash flow to total debt, and debt to asset to financial distress. The number of sample are 24 mining sector companies in Indonesia Stock Exchange year 20122016. Data collection method using non-participant observation and logistic regression as data analysis technique. The results found that: current asset turnover has negative influence not significantly to financial distress, total asset turnover has a negative influence significantly to financial distress, days sales in receivables has positive influence not significantly to financial distress, cash flow to total debt has negative influence not significantly to financial distress, and debt to asset has positive influence significantly to financial distress.

Keywords: financial condition, financial distress, and logistic regression. 


\section{PENDAHULUAN}

Kondisi keuangan merupakan suatu keadaan yang menunjukkan tingkat kesehatan perusahaan yang sesungguhnya. Perusahaan dengan kondisi keuangan yang tidak sehat pada umumnya dapat dilihat dari adanya masalah pada perusahaan dalam menjaga keberlangsungan usaha (Ramadhany, 2004). Perusahaan yang mengalami financial distress dapat menyebabkan perusahaan tidak memiliki kemampuan untuk tetap menjaga keberlangsungan usahanya, dan apabila hal ini tidak ditanggulangi dengan tepat maka perusahaan akan mengalami kebangkrutan. Kebangkrutan merupakan persoalan yang serius dan memakan biaya, jika ada suatu early warning system yang dapat memprediksi adanya tandatanda bahwa perusahaan akan mengalami financial distress maka hal ini akan dapat sangat membantu perusahaan untuk melakukan pencegahan sedini mungkin dan meminimalisir kemungkinan perusahaan menuju kearah kebangkrutan (Hanafi, 2016: 654).

Perusahaan yang sedang mengalami financial distress dapat dilihat dengan berbagai cara dan salah satunya yaitu dari rasio Earning per Share (EPS). EPS pada dasarnya dapat digunakan sebagai proksi dari financial distress karena rasio ini banyak digunakan oleh pemegang saham dalam menilai bagaimana prospek perusahaan di masa mendatang dibandingkan dengan rasio-rasio keuangan lainnya. Suatu perusahaan memiliki pertumbuhan yang baik di masa mendatang apabila memiliki EPS yang positif secara terus-menerus pada setiap periodenya. Perusahaan yang dapat dikategorikan mengalami kondisi financial distress adalah perusahaan yang memiliki nilai EPS negatif karena ini menandakan bahwa 
perusahaan sedang mengalami rugi usaha akibat dari pendapatan yang diterima perusahaan pada periode tersebut lebih kecil daripada biaya yang dikeluarkan. Pada umumnya rasio-rasio keuangan digunakan sebagai variabel bebas dalam meneliti financial distress perusahaan karena rasio keuangan mencerminkan kinerja perusahaan pada peridode tersebut.

Current asset turnover memiliki pengaruh negatif terhadap financial distress sehingga current asset turnover yang tinggi dapat menyebabkan probabilitas suatu perusahaan dalam mengalami kondisi financial distress akan menjadi semakin rendah karena adanya perputaran aktiva lancar akan dapat menghasilkan arus kas masuk ke dalam perusahaan (Ong et al., 2011). Hasil penelitian serupa juga ditemukan oleh Low et al. (2001) dan Yunus et al. (2017). Perbedaan hasil penelitian oleh Charitou et al. (2004) dan Bhunia et al. (2011) menemukan bahwa current asset turnover tidak berpengaruh signifikan memprediksi terjadinya financial distress.

Penelitian oleh Jiming dan Weiwei (2011), Hanifah dan Purwanto (2013), Widhiari dan Merkusiwati (2015), Noviandri (2014), serta Yudiawati dan Indriani (2016) dalam penelitian yang dilakukan menemukan variabel total asset turnover memiliki pengaruh signifikan terhadap financial distress. Perbedaan hasil penelitian ditemukan oleh Karas dan Reznakova (2017) yaitu total asset turnover tidak memiliki pengaruh signifikan dalam memprediksi kebangkrutan. Penelitian lain yang mendukung hasil penelitian ini adalah Yap et al. (2012), Yunus et al. (2017), Widarjo dan Setiawan (2009), serta Charitou et al. (2004) menemukan bahwa total asset turnover tidak signifikan dalam memprediksi financial distress. 
Bhunia et al. (2011), dan Ong et al. (2011) dalam penelitian yang dilakukan menemukan bahwa days sales in receivable adalah variabel yang memiliki hubungan yang positif dan signifikan untuk memprediksi financial distress. Penelitian lain oleh Yunus et al. (2017) serta Zeytinoglu dan Akarim (2013) menemukan bahwa days sales in receivable tidak signifikan dalam memprediksi financial distress.

Yap et al. (2012), Astuti dan Pamudji (2015), Ong et al. (2011), Platt dan Platt (2002) serta Almilia dan Kristijadi (2003) menemukan bahwa cash flow to total debt memiliki hubungan negatif dan signifikan dalam memprediksi financial distress. Hal ini menunjukkan bahwa cash flow to total debt yang tinggi akan membuat probabilitas suatu perusahaan mengalami financial ditress akan semakin menurun. Perbedaan hasil penelitian oleh Rashid dan Abbas (2011), Yunus et al. (2017), serta Bhunia et al. (2011) menemukan cash flow to total debt tidak berpengaruh signifikan memprediksi financial distress.

Charitou et al. (2004), Triwahyuningtias dan Muharam (2012), Yap et al. (2012), Hanifah dan Purwanto (2013), Yudiawati dan Indriani (2016), Yunus et al. (2017), serta Fahd and Benabdellah (2017) menemukan bahwa debt to asset merupakan rasio keuangan yang secara signifikan mampu memprediksi terjadinya financial distress. Perbedaan hasil penelitian oleh Widarjo dan Setiawan (2009) yang menguji pengaruh dari rasio keuangan terhadap financial distress menemukan bahwa debt to asset tidak berpengaruh terhadap financial distress.

Berdasarkan data publikasi Bursa Efek Indonesia (2014; 2016), sektor pertambangan berada pada kondisi mengalami kerugian yang terbesar 
dibandingkan dengan sektor-sektor lain di BEI tepatnya pada bulan Desember 2014 yaitu sebesar 14,92 persen dan pada bulan Januari 2016 sebesar 14,62 persen. Hal ini disebabkan oleh jatuhnya harga komoditi di sektor pertambangan, berkurang permintaan terhadap komoditi di sektor pertambangan untuk negara tujuan ekpor karena dampak dari perlambatan ekonomi yang melanda negara tujuan ekpor, serta terjadinya pelemahan nilai kurs mata uang rupiah.

Penelitian ini mereplikasi variabel dan teknik analisis data yang digunakan pada penelitian sebelumnya oleh Ong et al. (2011) yang menggunakan analisis regresi logistik untuk memprediksi kegagalan perusahaan yang terdaftar di bursa efek Malaysia. Berdasarkan hasil penelitian sebelumnya, maka penelitian ini menggunakan variabel seperti: current asset turnover, total asset turnover, days sales in receivable, cash flow to total debt, dan debt to asset terhadap financial distress. Hal ini karena dari 11 rasio keuangan yang diteliti hanya terdapat lima rasio yang berpengaruh signifikan dalam memprediksi financial distress. Penelitian ini dilakukan pada perusahaan sektor pertambangan di Bursa Efek Indonesia (BEI) dari tahun 2012-2016.

Berdasarkan latar belakang di atas maka yang menjadi pokok permasalahan dalam penelitian ini adalah: 1) Bagaimana pengaruh current asset turnover dalam memprediksi financial distress pada perusahaan sektor pertambangan di BEI?, 2) Bagaimana pengaruh total asset turnover dalam memprediksi financial distress pada perusahaan sektor pertambangan di BEI?, 3) Bagaimana pengaruh days sales in receivables dalam memprediksi financial distress pada perusahaan sektor pertambangan di BEI?, 4) Bagaimana pengaruh cash flow to total debt dalam 
memprediksi financial distress pada perusahaan sektor pertambangan di BEI?, dan 5) Bagaimana pengaruh debt to asset dalam memprediksi financial distress pada perusahaan sektor pertambangan di BEI?.

Penelitian ini bertujuan untuk mengetahui pengaruh dari masing-masing variabel, seperti: pengaruh current asset turnover dalam memprediksi financial distress pada perusahaan sektor pertambangan di BEI, pengaruh dari total asset turnover dalam memprediksi financial distress pada perusahaan sektor pertambangan di BEI, pengaruh dari days sales in receivables dalam memprediksi financial distress pada perusahaan sektor pertambangan di BEI, pengaruh dari cash flow to total debt dalam memprediksi financial distress pada perusahaan sektor pertambangan di BEI, serta pengaruh dari debt to asset dalam memprediksi financial distress pada perusahaan sektor pertambangan di BEI.

Financial distress merupakan suatu tahap penurunan kondisi keuangan yang terjadi sebelum terjadinya likuidasi maupun kebangkrutan. Menurut Shaari et al. (2013) menyatakan bahwa financial distress dapat diakibatkan oleh kemampuan perusahaan dalam menghasilkan laba dari proses operasinya yang rendah. Financial distress perusahaan mengacu pada keadaan keuangan yang genting akibat dari adanya kemunduran eksternal atau kegagalan pengendalian keuangan secara internal (Zhang et al., 2013). Sebuah perusahaan dianggap mengalami financial distress ketika terjadi hal-hal seperti mengalami laba operasi bersih negatif selama beberapa tahun, penghentian pembayaran deviden, restrukturisasi keuangan atau PHK massal (Wongsosudono dan Chrissa, 2013). Yayanti dan Yanti (2015) menyatakan bahwa financial distress juga dapat diukur dengan 
Ni Kadek Tina Rasminiati, Prediksi Kondisi Keuangan pada...

menggunakan salah satu rasio keuangan yaitu Earning per Share (EPS). EPS merupakan ukuran dari laba bersih pada setiap lembar saham yang dapat menggambarkan seberapa besar perusahaan dapat menghasilkan keuntungan per lembar saham yang akan dibagikan kepada pemilik saham (Krisnayanti dan Merkusiwati, 2014).

Current asset turnover merupakan rasio yang menunjukkan kemampuan perusahaan menghasilkan penjualan berdasarkan pada aktiva lancar yang dimiliki perusahaan. Current asset turnover dihitung dengan membandingkan antara penjualan dengan aktiva lancar. Menurut Ong et al. (2011) menemukan bahwa current asset turnover memiliki pengaruh negatif signifikan terhadap financial distress pada taraf signifikansi 1 persen. Current asset turnover yang tinggi akan menyebabkan kemungkinan perusahaan mengalami financial distress akan semakin rendah. Hal ini karena ketika perusahaan produktif dalam menghasilkan penjualan atau pendapatan maka akan terdapat arus kas yang masuk ke perusahaan, sehingga dengan adanya aliran arus kas masuk ini akan dapat mengurangi risiko perusahaan akan mengalami financial distress. Penelitian ini juga didukung oleh Low et al. (2001), serta Yunus et al. (2017).

$\mathrm{H}_{1}$ : Current asset turnover (CATO) berpengaruh negatif dan signifikan terhadap financial distress pada perusahaan sektor pertambangan di BEI.

Total asset turnover (TATO) atau perputaran total aset merupakan rasio yang melihat sejauh mana keseluruhan aset yang dimiliki oleh perusahaan terjadi perputaran secara efektif (Fahmi, 2016: 80). Total asset turnover yang rendah menunjukkan bahwa perusahaan belum mampu memaksimalkan aktiva yang 
dimiliki dan begitupula sebaliknya (Kasmir, 2010: 186). Yudiawati dan Indriani (2016) menemukan bahwa total asset turnover memiliki pengaruh negatif dan signifikan terhadap financial distress. Total asset turnover yang semakin tinggi akan membuat kemungkinan terjadinya financial distress di suatu perusahaan akan semakin rendah dan begitupula sebaliknya total asset turnover yang rendah akan membuat probabilitas perusahan mengalami financial distress akan semakin tinggi. Hasil penelitian ini didukung oleh penelitian lain seperti: Jiming dan Weiwei (2011), Hanifah dan Purwanto (2013), Widhiari dan Merkusiwati (2015), serta Noviandri (2014).

$\mathrm{H}_{2}$ : Total assets turnover (TATO) berpengaruh negatif dan signifikan terhadap financial distress pada perusahaan sektor pertambangan di BEI.

Days Sales in Receivable (DSR) menunjukkan berapa lama piutang dagang dari hasil penjualan tertagih menjadi kas. Periode penagihan piutang yang semakin pendek menunjukkan perusahaan bekerja secara efektif, namun apabila days sales in receivable tinggi, hal ini menunjukkan bahwa terdapat kelemahan pada bagian penagihan piutang karena dana yang tertanam pada piutang menjadi semakin besar (Hanafi, 2016: 38). Bhunia et al. (2011) dalam penelitian yang dilakukan pada perusahaan di India menemukan variabel days sales in receivable berpengaruh signifikan terhadap financial distress. Penelitian tersebut dapat memprediksi sebesar 76,6 persen perusahaan yang mengalami financial distress dan 87,5 persen perusahaan yang tidak mengalami financial distress secara tepat. Penelitian ini didukung oleh Ong et al. (2011) yang menemukan hasil serupa. 
Ni Kadek Tina Rasminiati, Prediksi Kondisi Keuangan pada...

$\mathrm{H}_{3}$ : Days sales in receivable (DSR) berpengaruh positif dan signifikan terhadap financial distress pada perusahaan sektor pertambangan di BEI.

Cash flow to total debt merupakan kemampuan perusahaan dalam menggunakan arus kas yang dimiliki untuk membayar jumlah utang perusahaan. Cash flow to total debt diukur dari hasil dari laba sebelum pajak, bunga, depresiasi, dan amortisasi. Menurut Astuti dan Pamudji (2015) dalam penelitiannya menemukan bahwa variabel arus kas berpengaruh negatif dan signifikan terhadap kemungkinan financial distress. Semakin kecil arus kas yang dimiliki perusahaan maka akan semakin besar kemungkinan perusahaan mengalami financial distress dan begitupula sebaliknya. Penelitian ini didukung oleh penelitian lain seperti: Yap et al. (2012), Ong et al. (2011), Platt dan Platt (2002), serta Almilia dan Kristijadi (2003).

$\mathrm{H}_{4}$ : Cash flow to total debt (CFD) berpengaruh negatif dan signifikan terhadap financial distress pada perusahaan sektor pertambangan di BEI.

Debt to asset merupakan rasio yang menunjukkan seberapa banyak perusahaan dibayai oleh utang. Menurut Hanafi (2016:41) debt to asset yang tinggi menunjukkan bahwa perusahaan menggunakan utang/ financial leverage yang tinggi. Hal ini didukung oleh penelitian yang dilakukan Fahd dan Benabdellah (2017) yang menemukan bahwa debt to asset memiliki pengaruh positif dan signifikan yang berarti bahwa debt to asset yang tinggi menunjukkan kemungkinan perusahaan mengalami kebangkrutan juga akan semakin tinggi dan sebaliknya. Hasil penelitian serupa juga ditemukan oleh Yunus et al. (2017), 
Yudiawati dan Indriani (2016), Hanifah dan Purwanto (2013), Triwahyuningtias dan Muharam (2012), serta Yap et al. (2012).

$\mathrm{H}_{5}$ : Debt to asset (DAR) berpengaruh positif dan signifikan terhadap financial distress pada perusahaan sektor pertambangan di BEI.

\section{METODE PENELITIAN}

Desain penelitian yang digunakan dalam penelitian ini menggunakan model Regresi Logistik. Pendekatan yang digunakan dalam penelitian ini adalah pendekatan kuantitatif berbentuk asosiatif, yaitu untuk mengetahui pengaruh dari current asset turnover, total asset turnover, days sales in receivable, cash flow to total debt, dan debt to asset terhadap financial distress pada perusahaan sektor pertambangan di BEI periode 2012-2016. Variabel dependen (variabel terikat) yang digunakan dalam penelitian ini adalah variabel financial distress dan variabel independennya (variabel bebas) adalah current assets turnover, total assets turnover, days sales in receivable, cash flow to total debt, dan debt to asset.

Variabel dummy digunakan untuk mengukur financial distress dimana nilai yang diberikan yaitu nilai 0 untuk perusahaan yang tidak mengalami financial distress dan nilai 1 untuk perusahaan yang mengalami financial distress. Perusahaan dengan kategori tidak mengalami financial distress yaitu perusahaan yang memiliki nilai EPS positif selama dua tahun berturut-turut, sedangkan perusahaan kategori mengalami financial distress adalah perusahaan yang memiliki nilai EPS negatif selama dua tahun berturut-turut.

Current asset turnover dihitung dengan membandingkan antara penjualan dengan aktiva lancar pada perusahaan sektor pertambangan di BEI dari tahun 
2012-2016. Satuan pengukuran current asset turnover adalah persentase yang dihitung dengan menggunakan rumuskan sebagai berikut:

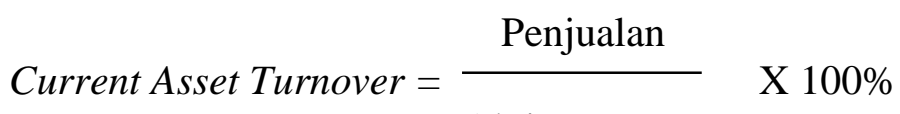

Aktiva Lancar

Total assets turnover diukur dengan membandingkan penjualan dengan total aset pada perusahaan sektor pertambangan di BEI dari tahun 2012-2016. Satuan pengukuran total asset turnover adalah persentase. Variabel ini dapat dihitung dengan menggunakan rumus berikut:

Total asset turnover $=\frac{\text { Penjualan }}{\text { Total Aset }} \times 100 \%$

Days sales in receivable dalam penelitian ini dihitung dengan membandingkan piutang dagang dan penjualan yang dibagi 365 pada perusahaan sektor pertambangan di BEI dari tahun 2012-2016. Satuan pengukuran days sales in receivable adalah hari yang dapat dihitung dengan rumus berikut:

Days sales in receivable $=\frac{\text { Piutang Dagang }}{(\text { Penjualan } / 365)}$

Cash flow to total debt diukur dari hasil dari laba sebelum pajak, bunga, depresiasi, dan amortisasi dibagi dengan total utang pada perusahaan sektor pertambangan di BEI dari tahun 2012-2016. Satuan pengukuran cash flow to total debt adalah persentase yang dihitung sebagai berikut:

$$
\text { Cash Flow to Total Debt }=\frac{\text { EBITDA }}{\text { Total Utang }} \times 100 \%
$$


Debt to asset diukur melalui perbandingan total utang dengan total aktiva pada perusahaan sektor pertambangan di BEI dari tahun 2012-2016. Satuan pengukuran debt to asset adalah persentase yang dirumuskan sebagai berikut:

Debt to asset $=\frac{\text { Total Utang }}{\text { Total Aset }} \times 100 \%$

Populasi yang digunakan dalam penelitian ini adalah semua perusahaan sektor pertambangan di Bursa Efek Indonesia (BEI) pada tahun 2012-2016 yaitu sebanyak 43 perusahaan. Teknik pengambilan sampel pada penelitian ini dilakukan dengan menggunakan teknik purposive sampling. Syarat pemilihan sampel tersebut yaitu: perusahaan sektor pertambangan di BEI yang menerbitkan laporan keuangan selama periode 2012-2016, perusahaan dalam sektor industri yang sama yaitu sektor pertambangan (tidak pernah berpindah sektor) selama periode 2012-2016, serta memiliki earnings per share negatif dalam 2 tahun berturut-turut untuk perusahaan kategori financial distress dan memiliki earnings per share positif dalam 2 tahun berturut-turut untuk perusahaan kategori tidak mengalami financial distress. Berdasarkan kriteria yang telah ditentukan, maka jumlah sampel pada penelitian ini yaitu 8 perusahaan dalam kategori financial distress dan 16 perusahaan dalam kategori tidak mengalami financial distress.

Jenis data yang digunakan dalam penelitian ini adalah data kuantitatif dan data kualitatif. Data sekunder pada penelitian ini adalah publikasi laporan keuangan pada Bursa Efek Indonesia. Metode pengumpulan data yang pada penelitian ini yaitu metode observasi non partisipan. Teknik analisis data yang digunakan pada penelitian ini yaitu analisis regresi logistik. Regresi logistik 
Ni Kadek Tina Rasminiati, Prediksi Kondisi Keuangan pada...

merupakan model cumulative distribution function (CDF) yang mampu menjamin nilai variabel terikat (Y) terletak antara 0 dan 1 sesuai dengan teori probabilitas. Regresi logistik digunakan ketika akan menguji apakah probabilitas terjadinya variabel terikat dapat diprediksi dengan menggunakan variabel bebasnya. Teknik analisis regresi logistik tidak memerlukan asumsi normalitas data dan uji asumsi klasik pada variabel bebasnya. Regresi logistik juga mengabaikan heteroskedatisitas yang berarti variabel dependen tidak memerlukan hemoskedastisitas untuk masing-masing variabel independen (Utama, 2016:137). Model umum regresi logistik yaitu sebagai berikut:

$$
\frac{p}{1-p}=e^{b 0+b 1 \times 1+b 2 x 2+b 3 \times 3+b 4 x 4+b 5 x 5}
$$

Keterangan:

$\mathrm{P} \quad=$ Probabilitas Variabel Dependen (Financial Distress)

e = Logaritma Natural

bo $\quad=$ Konstanta Regresi

$\mathrm{b}_{1} \quad=$ Konstanta Regresi 1

$\mathrm{b}_{2} \quad=$ Konstanta Regresi 2

$\mathrm{b}_{3} \quad=$ Konstanta Regresi 3

$\mathrm{b}_{4} \quad=$ Konstanta Regresi 4

$\mathrm{b}_{5} \quad=$ Konstanta Regresi 5

$\mathrm{x}_{1}=$ Current Asset Turnover

$\mathrm{x}_{2}=$ Total Asset Turnover

$\mathrm{x}_{3}=$ Days Sales in Receivable

$\mathrm{x}_{4} \quad=$ Cash Flow to Total Debt

$\mathrm{x}_{5}=$ Debt to Asset

\section{HASIL DAN PEMBAHASAN}

Variabel CATO (Current Asset Turnover) memiliki nilai minimum sebesar 0,064 yang terdapat pada PT. Bara Jaya Internasional Tbk. di tahun 2016, sedangkan nilai maksimum dari CATO sebesar 5,593 yaitu pada PT. Baramulti Suksessarana Tbk. tahun 2015. Nilai minimum dari variabel TATO (Total Asset 
Tunover) yakni 0,002 yang terdapat pada PT. Benakat Integra Tbk. di tahun 2016, sedangkan nilai maksimum TATO adalah sebesar 2,070 yang terdapat pada PT. Resource Alam Indonesia Tbk. di tahun 2012. Nilai minimum dari variabel DSR (Days Sales in Receivable) yakni 8,250 yang terdapat pada PT. Toba Bara Sejahtra Tbk. pada tahun 2014, sedangkan nilai maksimum DSR adalah sebesar 3.644,246 yang terdapat pada PT. Bara Jaya Internasional Tbk. tahun 2016. Variabel CFD (Cash Flow to Total Debt) memiliki nilai minimum -112,442 yaitu pada PT. SMR Utama Tbk. di tahun 2013, dan CFD memiliki nilai maksimum sebesar 222,987 yang terdapat pada PT. Golden Energy Mines Tbk. pada tahun 2013. Variabel DAR (Debt to Asset) memiliki nilai minimum sebesar 7,667 yang terdapat pada PT. SMR Utama Tbk. di tahun 2013, dan DAR memiliki nilai maksimum sebesar 106,749 yang terdapat pada PT. Energi Mega Persada Tbk. di tahun 2016.

Tabel 1.

Statistik Deskriptif Variabel Independen

\begin{tabular}{|c|c|c|c|c|c|}
\hline \multicolumn{6}{|c|}{ Descriptive Statistics } \\
\hline & $\mathrm{N}$ & Minimum & Maximum & Mean & Std. Deviation \\
\hline CATO & 120 & .064 & 5.593 & 1.79339 & 1.160076 \\
\hline TATO & 120 & .002 & 2.070 & .71651 & .495541 \\
\hline DSR & 120 & 8.250 & 3644.246 & 128.68497 & 366.301378 \\
\hline CFD & 120 & -112.442 & 222.987 & 33.61362 & 43.427089 \\
\hline DAR & 120 & 7.667 & 106.749 & 46.48206 & 18.681606 \\
\hline Valid N (listwise) & 120 & & & & \\
\hline
\end{tabular}

Sumber: Data Diolah, 2018

Tabel 2.

Frekuensi Variabel Terikat

\begin{tabular}{|c|c|c|c|c|c|}
\hline \multicolumn{6}{|c|}{ Financial Distress } \\
\hline & & Frequency & Percent & Valid Percent & $\begin{array}{c}\text { Cumulative } \\
\text { Percent }\end{array}$ \\
\hline \multirow{3}{*}{ Valid } & 0 & 80 & 66.7 & 66.7 & 66.7 \\
\hline & 1 & 40 & 33.3 & 33.3 & 100.0 \\
\hline & Total & 120 & 100.0 & 100.0 & \\
\hline
\end{tabular}

Sumber: Data Diolah, 2018 
Ni Kadek Tina Rasminiati, Prediksi Kondisi Keuangan pada...

Perusahaan sektor pertambangan yang mengalami financial distress diberi kode 1 dan untuk perusahaan yang tidak mengalami financial distress diberi kode 0. Berdasarkan Tabel di atas terdapat sebanyak 40 observasi $(33,3$ persen) perusahaan sektor pertambangan yang mengalami financial distress dan terdapat sebanyak 80 observasi (66,7 persen) perusahaan sektor pertambangan yang tidak mengalami financial distress selama tahun 2012-2016 di Bursa Efek Indonesia.

Tabel 3.

\begin{tabular}{cccc}
\multicolumn{4}{c}{ Uji Kelayakan Model } \\
\hline \multicolumn{4}{c}{ Hosmer and Lemeshow Test } \\
\hline Step & Chi-square & df & Sig. \\
\hline 1 & 7.967 & 8 & .437 \\
\hline Sumber: Data Diolah, 2018 & &
\end{tabular}

Berdasarkan hasil uji statistik Hosmer and Lemeshow Test, model regresi logistik pada penelitian memiliki nilai statistik sebesar 7,967 dengan probabilitas signifikansi 0,437. Nilai signifikansi dari Hosmer and Lemeshow Test yang lebih besar dari 0,05 memiliki arti bahwa model dalam penelitian ini dapat diterima dan sesuai dengan data observasinya.

Penilaian keseluruhan model dapat dilihat dari perbandingan nilai -2 Log likelihood pada awal (block number $=0$ ) dengan nilai -2 Log likelihood pada akhir (block number $=1$ ). Model regresi yang baik ditunjukkan apabila terjadi penurunan nilai dari -2 Log likelihood awal ke nilai -2 Log likelihood akhir (block number $=1$ ). Nilai -2 Log likelihood awal yaitu sebesar 152,763 dan setelah dimasukkan lima variabel independen nilai -2 Log likelihood akhir mengalami penurunan menjadi 90,796. Hal ini berarti bahwa model yang dihipotesiskan sesuai dengan data hasil penelitian keseluruhan model yang ditunjukkan pada tabel 4 dan tabel 5 . 
Tabel 4.

\begin{tabular}{|c|c|c|c|}
\hline \multicolumn{4}{|c|}{ Iteration History ${ }^{a, b, c}$ Block Number $=0$} \\
\hline \multicolumn{4}{|c|}{ Iteration History ${ }^{a, b, c}$} \\
\hline \multirow[t]{3}{*}{ Iteration } & & $-2 \log$ & Coefficients \\
\hline & & likelihood & Constant \\
\hline & 1 & 152.782 & -.667 \\
\hline \multirow{2}{*}{ Step 0} & 2 & 152.763 & -.693 \\
\hline & 3 & 152.763 & -.693 \\
\hline
\end{tabular}

b. Initial -2 Log Likelihood: 152.763

c. Estimation terminated at iteration number 3

because parameter estimates change by less than .001 .

Sumber: Data Diolah, 2018

Tabel 5.

\begin{tabular}{|c|c|c|c|c|c|c|c|c|}
\hline \multicolumn{9}{|c|}{$\begin{array}{l}\text { History }{ }^{a, b, c, d} \text { Block Numb } \\
\text { Iteration History } y^{a, b, c, d}\end{array}$} \\
\hline \multirow[t]{2}{*}{ Iteration } & & \multirow[t]{2}{*}{-2 Log likelihood } & \multicolumn{6}{|c|}{ Coefficients } \\
\hline & & & Constant & CATO & TATO & DSR & CFD & DAR \\
\hline \multirow{6}{*}{ Step 1} & 1 & 103.212 & -.536 & -.144 & -1.346 & .000 & -.005 & .026 \\
\hline & 2 & 92.712 & -.588 & -.247 & -2.048 & .001 & -.011 & .037 \\
\hline & 3 & 90.884 & -.624 & -.289 & -2.461 & .001 & -.015 & .044 \\
\hline & 4 & 90.796 & -.633 & -.292 & -2.578 & .001 & -.017 & .045 \\
\hline & 5 & 90.796 & -.634 & -.291 & -2.585 & .001 & -.017 & .046 \\
\hline & 6 & 90.796 & -.634 & -.291 & -2.585 & .001 & -.017 & .046 \\
\hline
\end{tabular}

a. Method: Enter

b. Constant is included in the model.

c. Initial -2 Log Likelihood: 152.763

d. Estimation terminated at iteration number 6 because parameter estimates changed by less than .001.

Sumber: Data Diolah, 2018

Tabel 6.

Model Summary

\begin{tabular}{lccc}
\hline Step & $\begin{array}{c}-2 \mathrm{Log} \\
\text { likelihood }\end{array}$ & $\begin{array}{c}\text { Cox \& Snell R } \\
\text { Square }\end{array}$ & $\begin{array}{l}\text { Nagelkerke R } \\
\text { Square }\end{array}$ \\
\hline 1 & $90.796^{\mathrm{a}}$ & .403 & .560 \\
\hline a. Estimation terminated at iteration number & 6 because \\
parameter estimates changed by less than .001. & \\
Sumber: Data Diolah, 2018 & &
\end{tabular}

Nilai dari Nagelkerke $R$ Square menunjukkan seberapa kuat hubungan antara variabel independen terhadap variabel dependen. Berdasarkan data yang terdapat pada tabel 5, nilai Nagelkerke $R$ Square yaitu sebesar 0,560. Nilai Nagelkerke $R$ Square 0,560 ini memiliki arti bahwa sebesar 56 persen variabel independen yang digunakan dalam model penelitian ini yang terdiri dari vaiabel 
Ni Kadek Tina Rasminiati, Prediksi Kondisi Keuangan pada...

current asset turnover (CATO), total asset turnover (TATO), days sales in receivable (DSR), cash flow to total debt (CFD), dan debt to asset (DAR) mampu menjelaskan variabel dependen (financial distress), sedangkan sisanya sebesar 44 persen dijelaskan oleh variabel lainnya yang tidak dimasukkan ke dalam model persamaan regresi.

Tabel 7.

Correlation Matrix

\begin{tabular}{rlrrrrrr}
\hline & & \multicolumn{1}{c}{ Constant } & \multicolumn{1}{c}{ CATO } & \multicolumn{1}{c}{ TATO } & \multicolumn{1}{c}{ DSR } & \multicolumn{1}{c}{ CFD } & \multicolumn{1}{c}{ DAR } \\
\hline \multirow{5}{*}{ Step 1 } & Constant & 1.000 & -.355 & .055 & -.325 & -.071 & -.698 \\
& CATO & -.355 & 1.000 & -.591 & .242 & -.245 & -.043 \\
& TATO & .055 & -.591 & 1.000 & .015 & -.089 & -.225 \\
& DSR & -.325 & .242 & .015 & 1.000 & .042 & -.069 \\
& CFD & -.071 & -.245 & -.089 & .042 & 1.000 & .090 \\
& DAR & -.698 & -.043 & -.225 & -.069 & .090 & 1.000 \\
\hline
\end{tabular}

Sumber: Data Diolah, 2018

Nilai koefisien korelasi antar variabel berdasarkan data pada tabel 7 memiliki nilai yang lebih kecil dari 0,8 (nilai koefisien korelasi antar variabel < 0,8). Nilai koefisien korelasi antar variabel yang lebih kecil ini menunjukkan bahwa tidak terdapat gejala multikolinearitas yang serius antar variabel bebas dalam model penelitian ini.

Tabel 8.

Matriks Kualifikasi

\begin{tabular}{|c|c|c|c|c|c|}
\hline \multicolumn{6}{|c|}{ Classification Table $^{a}$} \\
\hline & \multirow{3}{*}{\multicolumn{2}{|c|}{ Observed }} & \multicolumn{3}{|c|}{ Predicted } \\
\hline & & & \multicolumn{2}{|c|}{ Financial Distress } & \multirow{2}{*}{$\begin{array}{c}\text { Percentage } \\
\text { Correct }\end{array}$} \\
\hline & & & 0 & 1 & \\
\hline \multirow{3}{*}{ Step 1} & \multirow{2}{*}{ FD } & 0 & 70 & 10 & 87.5 \\
\hline & & 1 & 12 & 28 & 70.0 \\
\hline & \multicolumn{4}{|c|}{ Overall Percentage } & 81.7 \\
\hline
\end{tabular}

a. The cut value is .500

Sumber: Data Diolah, 2018

Hasil analisis pada Tabel 8 menunjukkan bahwa pada ketepatan observasi pengelompokan perusahaan pada sektor pertambangan yang tidak mengalami financial distress (kode 0) adalah sebesar 87,5 persen. Ketepatan observasi 
klasifikasi pada perusahaan pada sektor pertambangan yang mengalami financial distress (kode 1) adalah sebesar 70 persen. Ketepatan klasifikasi pada model regresi ini secara keseluruhan dalam pengelompokkan perusahaan sektor pertambangan yang tidak mengalami financial distress dan perusahaan yang mengalami financial distress adalah sebesar 81,7 persen.

Tabel 9.

Pengujian Model Regresi Logistik

\begin{tabular}{|c|c|c|c|c|c|c|c|}
\hline \multicolumn{8}{|c|}{ Variables in the Equation } \\
\hline & & B & S.E. & Wald & $\mathrm{df}$ & Sig. & $\operatorname{Exp}(B)$ \\
\hline \multirow{6}{*}{ Step $1^{a}$} & CATO & -.291 & .479 & .370 & 1 & .543 & .747 \\
\hline & TATO & -2.585 & 1.056 & 5.997 & 1 & .014 & .075 \\
\hline & DSR & .001 & .001 & .161 & 1 & .688 & 1.001 \\
\hline & CFD & -.017 & .011 & 2.422 & 1 & .120 & .983 \\
\hline & DAR & .046 & .015 & 8.732 & 1 & .003 & 1.047 \\
\hline & Constant & -.634 & .885 & .513 & 1 & .474 & .531 \\
\hline
\end{tabular}

a. Variable(s) entered on step 1: CATO, TATO, DSR, CFD, DAR.

Sumber: Data Diolah, 2018

Berdasarkan data yang terdapat pada tabel 9, model regresi yang terbentuk berdasarkan atas nilai estimasi parameter dalam variables in equation adalah sebagai berikut.

$\operatorname{Ln} \frac{p}{p-1}=-0,634-0,291$ CATO-2,585 TATO+0,001 DSR-0,017 CFD+0,046 DAR

\section{Pengaruh current asset turnover (CATO) terhadap financial distress.}

Variabel current assets turnover (CATO) menunjukkan nilai koefisien regresi sebesar -0,291 dengan nilai probabilitas variabel sebesar 0,543> $\alpha=0,05$. Hasil ini mengandung arti bahwa variabel CATO memiliki pengaruh negatif namun tidak signifikan secara statistik terhadap financial distress karena memiliki nilai probabilitas variabel yang lebih besar dari $\alpha 5$ persen, sehingga hipotesis 1 $\left(\mathrm{H}_{1}\right)$ yang menyatakan bahwa current asset turnover (CATO) memiliki pengaruh 
Ni Kadek Tina Rasminiati, Prediksi Kondisi Keuangan pada...

negatif dan signifikan terhadap financial distress pada perusahaan sektor pertambangan di BEI, ditolak.

Hasil penelitian ini sesuai dengan temuan Charitou et al. (2004) yang melakukan penelitian pada perusahaan industri publik di UK dengan jumlah sampel penelitian yaitu sebanyak 51 perusahaan dengan kategori mengalami kebangkrutan dan 51 perusahaan dengan kategori sehat. Hasil penelitian Charitou et al. (2004) menunjukkan bahwa current asset turnover tidak signifikan dalam memprediksi terjadinya financial distress. Hasil yang tidak signifikan ini karena nilai current asset turnover yang terlalu tinggi akan dapat mengganggu likuiditas perusahaan. Besarnya nilai aktiva lancar yang digunakan untuk menghasilkan barang yang akan diproduksi mengindikasikan bahwa manajemen perusahaan tersebut memiliki kemampuan untuk mengelola aktiva lancar yang dimiliki untuk menghasilkan laba bagi perusahaan, namun belum dilakukan secara maksimal. Penelitian yang dilakukan oleh Charitou et al. (2004) didukung oleh hasil penelitian lain yang serupa seperti yang dilakukan oleh Bhunia et al. (2011).

\section{Pengaruh total asset turnover (TATO) terhadap financial distress.}

Nilai koefisien regresi dari variabel total asset turnover (TATO) adalah sebesar $-2,585$ dengan nilai probabilitas variabel yaitu $0,014<\alpha=0,05$. Variabel total asset turnover (TATO) memiliki pengaruh yang negatif dan signifikan secara statistik terhadap financial distress karena memiliki nilai probabilitas variabel yang lebih kecil dari tingkat $\alpha 5$ persen, sehingga hipotesis $2\left(\mathrm{H}_{2}\right)$ yang menyatakan bahwa total asset turnover (TATO) memiliki pengaruh negatif dan 
signifikan terhadap financial distress pada perusahaan sektor pertambangan di BEI, diterima.

Variabel total asset turnover merupakan rasio yang menunjukkan efektivitas suatu perusahaan dalam penggunaan aktiva yang dimiliki untuk menghasilkan penjualan. Perusahaan yang tidak beroperasi pada volume yang memadai terhadap kapasitas investasi disertai dengan terjadinya penurunan yang besar mengindikasikan bahwa aset yang digunakan tidak efisien sehingga hal ini dapat menyebabkan terjadinya keterlambatan atau berkurangnya pengembalian dana dalam bentuk kas yang menunjukkan rendahnya perputaran total aktiva. Total asset turnover yang rendah menyebabkan probabilitas suatu perusahaan mengalami financial distress akan semakin besar.

Hasil penelitian sebelumnya mengenai variabel current asset turnover yang tidak signifikan terhadap financial distress mengindikasikan bahwa pada total aset peran dari aktiva tetap memberikan kontribusi besar dalam memprediksi financial distress pada perusahaan sektor pertambangan di BEI periode 2012-2016. Hal ini menunjukkan bahwa perusahaan secara efektif harus dapat memaksimalkan perputaran aktiva tetap yang digunakan untuk menghasilkan penjualan, sehingga hal tersebut akan dapat meminimalisir perusahaan dari terjadinya financial distress. Aktiva tetap merupakan salah satu aset perusahaan dengan biaya yang besar terkandung didalamnya, sehingga pemanfaatan aktiva tetap untuk menghasilkan penjualan harus dapat dilakukan secara optimal untuk menghasilkan laba bagi perusahaan. 
Ni Kadek Tina Rasminiati, Prediksi Kondisi Keuangan pada...

Hasil penelitian ini sesuai dengan temuan Yudiawati dan Indriani (2016) yang menemukan bahwa total asset turnover berpengaruh negatif signifikan terhadap financial distress. Hal ini berarti bahwa semakin tinggi total asset turnover maka semakin rendah kemungkinan terjadinya financial distress di suatu perusahaan dan begitu juga sebaliknya ketika total asset turnover semakin rendah maka kemungkinan perusahaan mengalami financial distress akan menjadi semakin tinggi. Hasil penelitian ini didukung oleh penelitian lain diantaranya yakni Jiming dan Weiwei (2011), Hanifah dan Purwanto (2013), Noviandri (2014), serta Widhiari dan Merkusiwati (2015).

\section{Pengaruh days sales in receivable (DSR) terhadap financial distress.}

Nilai koefisien regresi dari variabel days sales in receivable (DSR) adalah sebesar 0,001 dengan nilai probabilitas variabel sebesar 0,688> $\alpha=0,05$. Hasil ini berarti bahwa variabel days sales in receivable memiliki pengaruh positif namun tidak signifikan secara statistik terhadap financial distress karena memiliki nilai probabilitas variabel yang lebih besar dari tingkat $\alpha 5$ persen, sehingga hipotesis 3 $\left(\mathrm{H}_{3}\right)$ yang menyatakan bahwa days sales in receivable (DSR) memiliki pengaruh positif dan signifikan terhadap financial distress pada perusahaan sektor pertambangan di BEI, ditolak.

Hasil pengujian ini sesuai dengan temuan Yunus et al. (2017) dalam penelitiannya yang menggunakan sampel sebanyak 85 perusahaan dengan kategori sehat dan 50 perusahaan dengan kategori mengalami kebangkrutan pada perusahaan sektor industri manufaktur di Malaysia tahun 2008-2012. Penelitian ini menemukan bahwa days sales in receivable tidak signifikan dalam 
memprediksi financial distress. Hasil penelitian serupa juga ditemukan oleh Zeytinoglu dan Akarim (2013).

\section{Pengaruh cash flow to total debt (CFD) terhadap financial distress.}

Nilai probabilitas dari variabel cash flow to total debt (CFD) adalah sebesar $0,12>\alpha=0,05$ dengan nilai koefisien regresi sebesar $-0,017$. Hasil ini memiliki arti bahwa variabel cash flow to total debt memiliki pengaruh negatif dan tidak signifikan secara statistik terhadap financial distress karena memiliki nilai probabilitas variabel yang lebih besar dari $\alpha 5$ persen. Hipotesis $4\left(\mathrm{H}_{4}\right)$ yang menyatakan bahwa cash flow to total debt (CFD) memiliki pengaruh negatif dan signifikan terhadap financial distress pada perusahaan sektor pertambangan di BEI, ditolak.

Hasil pengujian ini sesuai dengan temuan Yunus et al. (2017) dalam penelitian yang dilakukan menemukan variabel cash flow to total debt tidak signifikan secara statistik dalam memprediksi financial distress pada perusahaan industri manufaktur di Malaysia periode tahun 2008-2012. Jumlah sampel yang digunakan dalam penelitian ini adalah sebanyak 185 sampel yang menjadi objek observasi terdiri dari 85 perusahaan yang sehat dan 50 perusahaan yang mengalami kebangkrutan. Hasil penelitian ini juga didukung oleh Rashid dan Abbas (2011) yang menyatakan variabel cash flow to total debt tidak signifikan secara statistik dalam memprediksi perusahaan yang mengalami financial distress di Pakistan serta Bhunia et al. (2011). 


\section{Pengaruh debt to asset (DAR) terhadap financial distress.}

Nilai probabilitas variabel debt to asset adalah sebesar $0,003<=0,05$. dengan nilai koefisien regresi sebesar 0,046. Hasil ini memiliki arti debt to asset berpengaruh positif dan signifikan secara statistik terhadap financial distress karena nilai probabilitas variabel yang lebih kecil dari tingkat $\alpha 5$ persen. Ini menunjukkan bahwa hipotesis $5\left(\mathrm{H}_{5}\right)$ yang menyatakan bahwa debt to asset (DAR) memiliki pengaruh positif dan signifikan terhadap financial distress pada perusahaan sektor pertambangan di BEI, diterima.

Debt to asset menunjukkan seberapa besar aset yang dimiliki oleh suatu perusahaan diayai dengan utang. Debt to asset yang tinggi berarti bahwa besarnya pembiayaan dengan utang lebih tinggi dibandingkan dengan pembiayaan menggunakan ekuitas. Perusahaan akan sangat berisiko mengalami financial distress ketika memiliki utang yang lebih besar dari jumlah aset perusahaan dan cenderung melakukan pembiayaan banyak dengan menggunakan utang. Debt to asset yang memiliki pengaruh positif menunjukkan apabila nilai utang terhadap aset yang dimiliki perusahaan semakin besar maka kemungkinan perusahaan mengalami financial distress akan semakin tinggi dan sebaliknya ketika nilai utang terhadap aset perusahaan semakin kecil maka kemungkinan perusahaan mengalami financial distress akan semakin rendah.

Hasil penelitian ini serupa dengan penelitian yang dilakukan oleh Yudiawati dan Indriani (2016) yang melakukan penelitian pada perusahaan manufaktur yang terdaftar di BEI tahun 2012-2014, menemukan bahwa variabel debt to asset berpengaruh positif dan signifikan terhadap financial distress. Hasil 
penelitian ini didukung oleh penelitian lainnya, seperti: Fahd dan Benabdellah (2017), Charitou et al. (2004), Hanifah dan Purwanto (2013), Triwahyuningtias dan Muharam (2012), Yap et al. (2012), serta Yunus et al. (2017).

\section{IMPLIKASI HASIL PENELITIAN}

Implikasi teoritis dan praktis terdapat dalam penelitian ini. Implikasi teoritis dalam hasil penelitian ini menemukan variabel total asset turnover dan debt to asset signifikan dalam memprediksi financial distress pada perusahaan pertambangan di Bursa Efek Indonesia tahun 2012-2016. Total asset turnover memiliki hungan yang negatif dan signifikan dalam memprediksi financial distress. Hasil lainnya yaitu debt to asset juga signifikan dalam memprediksi financial distress dan memiliki hubungan yang positif. Nilai koefisien determinasi sebesar 0,56 mempunyai arti bahwa sebesar 56 persen variabel bebas dalam penelitian ini seperti: current asset turnover, total asset turnover, days sales in receivable, cash flow to total debt, dan debt to asset mampu menjelaskan variabel financial distress, dan sisanya sebesar 44 persen dijelaskan oleh variabel lain yang tidak dimasukkan dalam model persamaan regresi ini.

Implikasi praktis yaitu bagi para investor diharapkan dapat menggunakan penelitian ini sebagai acuan untuk menganalisis dan memilih perusahaan di sektor pertambangan yang tepat untuk berinvestasi, karena dengan pemilihan perusahaan yang tepat para investor akan dapat mendapatkan keuntungan yang optimal dan meminimalisir risiko perusahaan yang memiliki kemungkinan mengalami financial distress. Penelitian ini juga diharapkan supaya dapat dijadikan bahan pertimbangan bagi para eksekutif (pembuat keputusan) dalam mengambil suatu 
keputusan kedepannya dalam menanggulangi kemungkinan terjadinya financial distress yang dapat mengganggu aktivitas perusahaan, selain itu bagi pihak manajemen perusahaan diharapkan dengan adanya penelitian ini maka dapat memberikan motivasi untuk meningkatkan kinerja manajemen yang tercermin dari hasil laporan keuangan perusahaan.

\section{SIMPULAN DAN SARAN}

Berdasarkan hasil analisis data dan pembahasan maka penelitian ini dapat disimpulkan bahwa dari lima variabel yang diteli hanya terdapat dua variabel yang signifikan terhadap financial distress. Variabel tersebut adalah total asset turnover (TATO) dan debt to asset (DAR), sedangkan tiga variabel lainya seperti current asset turnover (CATO), days sales in receivableI (DSR), dan cash flow to total debt (CFD) tidak signifikan terhadap financial distress.

Total asset turnover menunjukkan seberapa besar perputaran total aktiva digunakan untuk menghasilkan penjualan. Total asset turnover tinggi ini menunjukkan bahwa perusahaan telah mengelola aktiva yang dimiliki untuk menghasilkan penjualan secara optimal sehingga hal tersebut akan dapat meningkatkan laba yang diperoleh oleh perusahaan dan adanya kemungkinan perusahaan mengalami suatu kondisi financial distress akan menurun.

Debt to asset menunjukkan bahwa sejauh mana perusahaan tersebut dibayai oleh utang. Debt to asset yang tinggi berarti bahwa proporsi pembiayaan utang yang tinggi dibandingkan pembiayaan ekuitas. Perusahaan yang memiliki jumlah utang yang lebih banyak dari jumlah aset perusahaan atau melakukan pembiayaan cenderung lebih banyak dengan menggunakan utang, maka perusahaan akan 
memiliki risiko yang tinggi untuk mengalami kesulitan keuangan (financial distress). Debt to asset memiliki pengaruh positif menunjukkan apabila nilai utang terhadap aset yang dimiliki perusahaan semakin tinggi maka probabilitas perusahaan tersebut mengalami financial distress akan semakin tinggi.

Berdasarkan hasil dari penelitian ini, adapun saran yang dapat diberikan yaitu: 1) Bagi pihak perusahaan khususnya yang bergerak di sektor pertambangan perlu untuk memperhatikan faktor yang memiliki pengaruh yang signifikan terhadap kemungkinan terjadinya financial distress seperti variabel total asset turnover dan debt to asset. Hal ini dikarenakan pengelolaan total aktiva yang efektif untuk menghasilkan penjualan akan dapat memberikan laba yang optimal bagi perusahaan sehingga kemungkinan perusahaan mengalami kondisi financial distress akan dapat dihindari. Rasio lainnya yang harus diperhatikan oleh pihak perusahaan yaitu debt to asset dimana perusahaan harus memperhatikan pengelolaan utang yang dimiliki karena apabila suatu perusahaan memiliki utang yang lebih besar daripada asetnya maka akan berisiko bagi perusahaan mengalami kondisi financial distress. 2) Bagi para investor dan calon investor yang ingin berinvestasi pada perusahaan pertambangan di BEI sebaiknya memperhatikan rasio keuangan perusahaan seperti total asset turnover dan debt to asset yang berpengaruh signifikan dalam memprediksi kondisi perusahaan yang mengalami financial distress, sehingga akan dapat meminimalkan risiko mengalami kerugian dari kemungkinan memilih perusahaan yang mengalami financial distress.

\section{REFERENSI}

Almilia, Luciana Spica dan Kristijadi. 2003. Analisis Rasio Keuangan untuk Memprediksi Kondisi Financial Distress Perusahaan Manufaktur yang 
Terdaftar Di Bursa Efek Jakarta. Jurnal Akuntansi dan Auditing Indonesia, 7(2), hal. 183-210.

Astuti, Puji dan Sugeng Pamudji. 2015. Analisis Pengaruh Opini Going Concern, Likuiditas, Solvabilitas, Arus Kas, Umur Perusahaan dan Ukuran Perusahaan Terhadap Kemungkinan Financial distress. Diponegoro Journal of Accounting, 4(1), hal. 1-11.

Bhunia, Amalendu, Sri Islam Uddin Khan, dan Somnath Mukhuti. 2011. Prediction of Financial Distress - A Case Study of Indian Companies. Asian Journal of Business Management, 3(3), pp. 210-218.

Bursa Efek Indonesia. 2016. IDX Yearly Statistics 2012-2016. Jakarta: IDX.

Charitou, Andreas, Evi Neophytou, dan Chris Charalambous. 2004. Predicting Corporate Failure: Empirical Evidence for the UK. European Accounting Review, 13(3), pp. 465-497.

Fahd, El-Ansari dan Pr. Majid Benabdellah. 2017. Prediction of Bankruptcy: Evidence from Moroccan Agricultural Companies. The International Journal of Business \& Management, 5(9), pp. 5-13.

Fahmi, Irham. 2016. Pengantar Manajemen Keuangan. Bandung: Alfabeta.

Hanafi, Mamduh M. 2016. Manajemen Keuangan. Yogyakarta: BPFE.

Hanifah, Oktita Earniing dan Agus Purwanto. 2013. Pengaruh Struktur Corporate Governance dan Financial Indicators Terhadap Kondisi Financial distress. Diponegoro Journal of Accounting, 2(2), hal. 1-15.

Jiming, Li dan Du Weiwei. 2011. An Empirical Study on the Corporate Financial Distress Predicton Based on Logistic Model : Evidence from China's Manufacturing Industry. International Journal of Digital Content Technology, 5(6), pp. 368-37.

Karas, Michal dan Maria Reznakova. 2017. The Potential Of Dynamic Indicator In Development Of The Bankruptcy Prediction Models: The Case Of Construction Companies. Acta Universitatis Agriculturae et Silviculturae Mendelianae Brunensis, 65(2), pp.641-652.

Kasmir. 2010. Analisis Laporan Keuangan. Jakarta: PT. Raja Grafindo Persada.

Krisnayanti, Ni Wayan Arwinda Putri dan Ni Kt. Lely A. Merkusiwati. 2014. Pengaruh Mekanisme Corporate Governance, Likuiditas, Leverage, Dan Ukuran PerusahaanPada Financial Distress. E-Jurnal Akuntansi Universitas Udayana, 7 (1), hal. 93-106. 
Low, Soo-Wah, Fauzias Mat Nor, dan Puan Yatim. 2001. Predicting Corporate Financial Distress Using The Logit Model: The Case of Malaysia. Asian Academy of Management Journal, 6(1), pp. 49-61.

Noviandri, Tio. 2014. Peranan Analisis Rasio Keuangan Dalam Memprediksi Kondisi Financial Distress Perusahaan Sektor Perdagangan. Jurnal Ilmu Manajemen, 2(4), hal. 16-55.

Ong, Shuk-Wern, Voon Choong Yap, dan Roy W.L. Khong. 2011. Corporate failure prediction: a study of public listed companies in Malaysia. Emerald Group Publishing Limited, 37(6), pp. 553-564.

Platt, Harlan D. dan Marjorie B. Platt. 2002. Predicting Corporate Financial Distress: Reflections on Choice Based Sample Bias. Journal of Economics and Finance, 26(2), pp. 184-199.

Ramadhany, Alexander. 2004. Analisis Faktor-Faktor yang Mempengaruhi Penerimaan Opini Going Concern Pada Perusahaan Manufaktur yang Terdaftar di BEJ. Thesis. Program Pasca Sarjana, Universitas Diponegoro.

Rashid, Abdul dan Qaiser Abbas. 2011. Predicting Bankruptcy in Pakistan. Theoretical and Applied Economics, 18(9), pp. 103-128.

Shaari, Noor Azizah, Nurfadhilah Abu Hasan, Yamuna Rani Palanimally, dan Rames Kumar Moona Haji Mohamed. 2013. The Determinants of Derivative Usage: A Study on Mallaysian Firms. Interdisciplinary Journal of Contemporary Research in Business, 5 (2), pp. shaa300-316.

Triwahyuningtias, Meilinda dan Harjum Muharam. 2012. Analisis Pengaruh Struktur Kepemilikan, Ukuran Dewan, Komisaris Independen, Likuiditas dan Leverage Terhadap Terjadinya Kondisi Financial Distress (Studi Pada Perusahaan Manufaktur yang Terdaftar di Bursa Efek Indonesia Tahun 2008-2010). Diponegoro Journal of Management, 1(1), hal. 1-14.

Utama, Made Suyana. 2016. Aplikasi Analisis Kuantitatif. Denpasar: CV. Sastra Utama.

Widarjo, W. dan Setiawan D. 2009. The Influence of Financial Ratio on Financial Distress in Automotive Companies. Jurnal Bisnis dan Akuntansi, 11(2), pp. 107-119.

Widhiari, Ni Luh Made Ayu dan Ni K. Lely Aryani Merkusiwati. 2015. Pengaruh Rasio Likuiditas, Leverage, Operating Capacity dan Sales Growth 
Terhadap Financial Distress. E-Jurnal Akuntansi Udayana, 11(2), hal. 456-469.

Wongsosudono, Corinna dan Chrissa. 2013 Analisis Rasio Keuangan Untuk Memprediksi Financial Distress Pada Perusahaan Sektor Keuangan yang Terdaftar di Bursa Efek Indonesia. Jurnal Bina Akuntansi, 19(2), hal. 114.

Yap, Ben Chin Fook, Shanmugam Munuswamy, dan Zulkifflee Bin Mohamed. 2012. Evaluating Company Failure in Malaysia Using Financial Ratios and Logistic Regression. Asian Journal of Finance \& Accounting, 4(1), pp. 330-344.

Yayanti, Vivian dan Yanti. 2015. Analisis Pengaruh Likuiditas, Efisiensi Operasi, dan Corporate Governance Terhadap Financial Distress Pada Perusahaan Manufaktur yang Terdaftar di Bursa Efek Indonesia Pada Periode 20122014. Jurnal Ekonomi, 20(1), hal. 154-173.

Yudiawati, Rike dan Astiwi Indriani. 2016. Analisis Pengaruh Current Ratio, Rasio Debt to Total Asset, Total asset turnover, dan Sales Growth Ratio Terhadap Kondisi Financial Distress (Studi Kasus Pada Perusahaan Manufaktur yang Terdaftar Di BEI Tahun 2012-2014). Diponegoro Journal of Management, 5(2), hal. 1-13.

Yunus, Fauziah Mohamad, Nurain Farahana Zainal Abidin, dan Norashikin Nasaruddin. 2017. Predicting Financial Distress Companies in Malaysia Manufacturing Industry Using Logistic Regression and Decision Tree Analysis. Journal of Business Management and Economic Studies, 2(2), pp. 91-101.

Zeytinoglu, Emin dan Yasemin Deniz Akarim. 2013. Financial Failure Prediction Using Financial Ratios: An Empirical Application on Istanbul Stock Exchange. Journal of Applied Finance \& Banking, 3(3), pp. 107-116.

Zhang, Ying, Chong $\mathrm{Wu}$, dan Xin-ying Zhang. 2013. Enterprise Financial Distress Prediction Based on BPNN: A Case Study of Chinese Listed Companies. Information Technology Journal, 12(23), pp. 7684-7690. 